\title{
Study the effect of cloned pET-32a(+) plasmid by Lysostaphin gene against Staphylococcus aureus
}

\author{
J.Y. Mustafa \\ Department of Public Health, College of Veterinary Medicine, University of Basra, Basra, Iraq
}

\begin{tabular}{l} 
Article information \\
\hline Article history: \\
Received February 21, 2020 \\
Accepted April 06, 2020 \\
Available online November 5, 2020 \\
\hline Keywords: \\
Effect \\
Cloned \\
pET-32a(+) \\
Lysostaphin \\
Gene \\
\hline Correspondence: \\
J.Y. Mustafa \\
dr.jalalyaseen1982@ yahoo.com
\end{tabular}

\begin{abstract}
Lysostaphin is a protein zinc metalloproteinase, extracted from Staphylococcus simulans, which disrupting peptide layer of S. aureus. In this study, Lysostaphin gene was detected in the $S$. simulans isolates. The molecular weight of the Lysostaphin gene is 750 bp. We were used the pET-32a(+) plasmid to cloning lysostaphin gene which transformed to competent rubidium chloride E. coli DH5 $\alpha$ for producing the lysostaphin protein. The lysostaphin protein from this gene which isolated from $S$. simulans, then used the expression of used to killed S. aureus, which has the thick layer of wall that is the very difficult bacteria response to treatment. The result was reported succeeded pET-32a (+) plasmid to expressed lysostaphin gene and gave lysostaphin protein with high quality and quantity. As well as the result was appeared the high accuracy of his tag method in protein extraction and purification, and the quality and quantity more than other studies.
\end{abstract}

DOI: 10.33899/ijvs.2020.126698.1362, (O2021, College of Veterinary Medicine, University of Mosul. This is an open access article under the CC BY 4.0 license (http://creativecommons.org/licenses/by/4.0/).

\section{Introduction}

Bacteriocins are bacterial proteinaceous compounds, which have the activity of bactericidal against other bacterial spp., the bacteriocins have been proteolytic degradation (1). This bacterial proteinaceous compounds produced by gram positive bacteria. The bacterial proteinaceous can be divided into four classes, classes I and II bacteriocins are the most studied and have better clarified mode of action, since they possess prospect industrial and clinical applications (2). Treatment of staphylococcal infections has become difficult increasingly due to resistant strains colonization to some of the antibiotics (3). Staphylococci can be eliminated by lysostaphin from skin and nares of individuals increased risk infections $S$. aureus (4). It is binds to $S$. aureus and pentaglycine cross bridges cleaves within peptidoglycan, the cell wall envelope removing and osmotic rupture precipitating of staphylococci (5). Lysostaphin primarily active against coagulase positive $S$. aureus but some activity residual against coagulase negative $S$. aureus, it is requiring increased enzyme concentration and longer times incubation to be killed (6). Lysostaphin gene from the $S$. simulans isolates contain $1.5 \mathrm{kbp}$ fragment of DNA (7). This gene was localized with in a Hpa II / Hind III fragment. The gene coding for preproenzyme which consist of three regions distinct: signal peptide at the end of aminoterminal, a series of tandem repeats and the active lysostaphin gene $(7,8)$. Promoter of the gene have $(--35)$ and (--10) at nucleotides regions (89-95) and (110-119), respectively (7).

There are a number of the reports of the lysostaphin expression promoter dopeptidase. In many study, the rlysostaphin produced from different pET vectors (9). One of the selective binding of the protein expressed is the His tags facilitate, it is affinity- nickel column. His tag sequences may be removed by protease optionally, another purification step requiring the tags which are no effect on the protein structure and function (10). Polyhistidines add by two ways. The first way by add repetitive histidine codons (CAT or CAC) to the PCR primers, as well as add 
start or stop codon. The second technique by add a encoding His-tag sequences protein to the vector (11).

The aim of this study to expressed lysostaphin gene by pET-32a (+) plasmid and using the lysostaphin protein as bactericidal of $S$. aureus.

\section{Materials and methods}

Isolated genomic DNA from $S$. simulans according to Sambrook and Russel (12) with modification. This DNA used as a template for the amplification. The annealing temperature used in the PCR program was $53^{\circ} \mathrm{C}$. The primer used in this study were Lys F1: (5' gct gca aca cat gaa cat tca 3'). Lys R1: (5' ctt tat agt tcc cca aag aac 3'). The total volume of PCR reaction was $50 \mu \mathrm{l}(5 \mu \mathrm{l} 10 \mathrm{X}$ buffer, $8 \mu 11.25 \mathrm{mM}$ of dNTPs, $2 \mu \mathrm{l}$ forward primer, $2 \mu \mathrm{l}$ reverse primer, $0.5 \mu \mathrm{l} P f x, 5 \mu \mathrm{l}$ enhancer, $0.5 \mu \mathrm{l}$ DNA template, $1 \mu \mathrm{l} \mathrm{MgSO}_{4}$, and $26 \mu \mathrm{l} \mathrm{ddH}_{2} \mathrm{O}$. The program of PCR technique consist of several stages: the first initial denaturation PCR program, $6 \mathrm{~min}$ at $95^{\circ} \mathrm{C}$. followed by 35 cycles $95^{\circ} \mathrm{C}$ for $45 \mathrm{sec}, 58^{\circ} \mathrm{C}$ for $45 \mathrm{sec}$, then $72^{\circ} \mathrm{C}$ for $45 \mathrm{sec}$. The last stage as $72^{\circ} \mathrm{C}$ for $6 \mathrm{~min}$, and then down to $4^{\circ} \mathrm{C}$ for $30 \mathrm{~min}$.

Then used primers have two restricted enzymes by add two restricted sits (Kpn I and EcoR I), one of them to the forward primer (Kpn I), the restrict sit for this enzyme (ggt acc) as well as start codon (atg), and the second one to the reverse primer (EcoR I), the restrict sit for this enzyme (gaa ttc) as well as stop codon (tca), and finally we are add codon of six histidine to the reverse primer in order to extract and purify the lysostaphin protein from cloning bacteria which have His tag sequences, the codon of one histidine (atg) add to revers primer, know, the last primers with two restricted sits (Kpn I and EcoR I) with start and stop codons and codon of six histidine are: Lys F2: 5' GGT ACC ATG GCT GCA ACA CAT GAA CAT TCA 3'. Lys R2: 5'GAA TTC TCA ATG ATG ATG ATG ATG ATG CTT TAT AGT TCC CCA AAG AAC 3'.

Table 1 show the run of PET-32a(+) plasmid in the gel after cut by two restrict enzymes (Kpn I and EcoR I), then isolated and purified by gel extraction kit from the gel.

The PCR products from first PCR by Lys F1 and Lys R1 used as a template for sub PCR by using Lys F2 and Lys $\mathrm{R} 2$. The PCR product was run to electrophoresis, then the DNA from the gel was isolated and purified by the kit of DNA extraction. The extracted gene was cut by two restricted enzymes ( $K p n \mathrm{I}$ and $E c o \mathrm{R} \mathrm{I}$ ) as represented in the table 2, then the cut away gene cleaned from the few bp posts cut by these enzymes.

Clones were done to study the effect of PET-32a $(+)$ plasmid, the cloning done between plasmid and PET-32a $(+)$ cuts by EcoR I and Kpn I enzymes. Then ligated gene of lysostaphin digested by enzymes with PET-32a(+) digest by the same enzyme as described above, then transformed to rubidium chloride E. coli $\mathrm{DH} 5 \alpha$.

Colonies were replica-plated onto fresh (LB) Luria Bertani solid medium, which containing $100 \mu \mathrm{g} / \mathrm{ml}$ ampicillin, then incubated overnight at $37^{\circ} \mathrm{C}$, then transformants bacteria confirmed by PCR, to detect successful cloning by colony PCR. This quick protocol which designed to screening the plasmids insert to the $E$. coli DH5 $\alpha$ and this plasmid has the insert. which is called (constructive plasmid).

Table 1: Digestion of pET-32a(+) by Kpn I and EcoR I enzymes

\begin{tabular}{lc}
\hline No. of Samples & No. of Infection \\
\hline pET-32A(+) & $20 \mu \mathrm{l}$ \\
10 X buffer & $5 \mu \mathrm{l}$ \\
BSA & $5 \mu \mathrm{L}$ \\
$\mathrm{ddH}_{2} \mathrm{O}$ & $16 \mu \mathrm{l}$ \\
$K p n$ I & $2 \mu \mathrm{l}$ \\
EcoR I & $2 \mu \mathrm{l}$ \\
\hline Total reaction & $50 \mu \mathrm{l}$ \\
\hline
\end{tabular}

Table 2: Digestion of gene of lysostaphin by EcoR I and Kpn I enzymes

\begin{tabular}{lc}
\hline Substance & Quantity \\
\hline Lysostaphin gene & $20 \mu \mathrm{l}$ \\
10X buffer & $5 \mu \mathrm{l}$ \\
$\mathrm{BSA}$ & $5 \mu \mathrm{l}$ \\
$\mathrm{ddH}_{2} \mathrm{O}$ & $16 \mu \mathrm{l}$ \\
$\mathrm{Kpn} \mathrm{I}$ & $2 \mu \mathrm{l}$ \\
Eco $\mathrm{R}$ I & $2 \mu \mathrm{l}$ \\
\hline Total reaction & $50 \mu \mathrm{l}$ \\
\hline
\end{tabular}

Determine the activity of cloning E. coli by lysostaphin gene to inhibit $S$. aureus by performed a standard disk diffusion assay. Prepare $S$. aureus and E. coli by culturing in the broth of nutrient to phase of exponential $\left(\mathrm{OD}_{620} 0.1\right)$. Then inoculated S. aureus were in the Muller - Hinton Agar (MHA), as well as prepared and placed in discs from E. coli in the plates centre. Overnight, under aerobic condition, incubated at $37^{\circ} \mathrm{C}$, determined the inhibition zones of culture.

Post determined the activity against $S$. aureus by cloning bacteria, we are extract and purify by His-tag method lysostaphin protein from cloning bacteria. This processing done by used the FF crude columns of HisTrap (Sweden), then determined the concentration of protein by Bio-Rad Protein Assay. By SDS-PAGE analysis, limited the purity of protein (13). 


\section{Results}

The result of this study in the figure 1 showed the result of electrophoresis of the total genomic DNA of S. simulans. In addition, the figure 2 showed the gel electrophoresis of pET-32a(+) plasmid and lysostaphin gene, this figure showed digested plasmid by Kpn I and EcoR I enzymes and digested gene of lysostaphin by same enzymes, which appeared the band of the gene about $750 \mathrm{bp}$. While figure 3 showing the product of lysostaphin gene from PCR cloned by pET-32a(+) plasmid by colony PCR, this figure showing band about $750 \mathrm{bp}$.

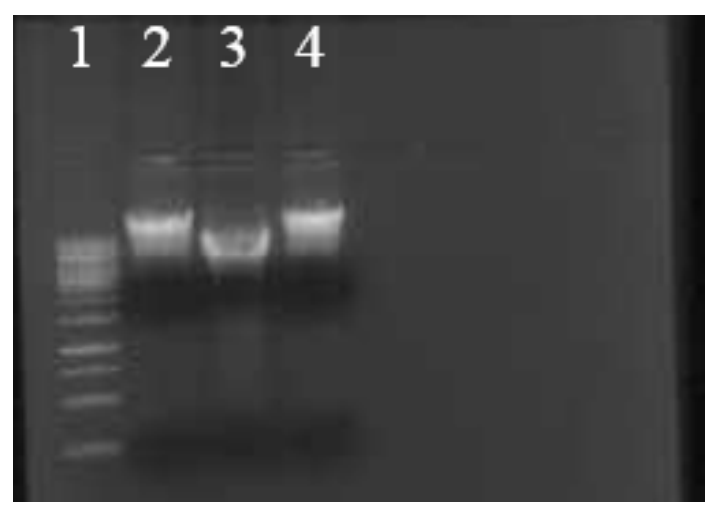

Figure 1: Electrophoresis of total genomic DNA of $S$. simulans, lane 1 is the ladder, lanes 2,3,4 are the total genomic DNA.

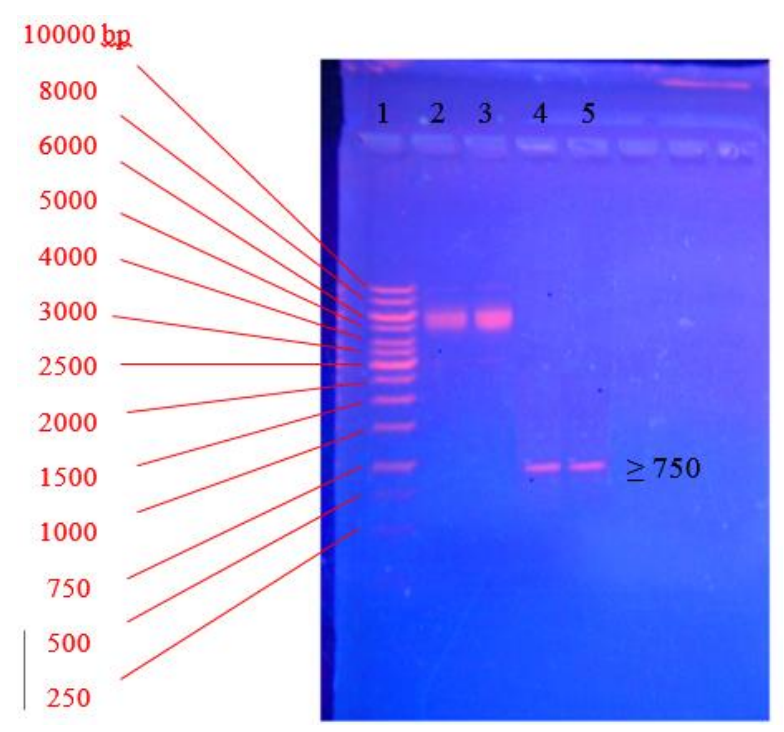

Figure 2: Gel electrophoresis of pET-32a(+) plasmid and lysostaphin gene, lane 1 is the ladder, lanes 2,3 digested plasmid by Kpn I and EcoR I enzymes and lanes 4,5 gene of lysostaphin digested by Kpn I and EcoR I enzymes.
The antibacterial activity of transformed $E$. coli have pET-32a(+) plasmid with gene of lysostaphin insert against S. aureus (Figure 4A), while figure 4B showed the effect of E. coli non-transformed by gene of lysostaphin against $S$. aureus. Table 3 showed the protein of lysostaphin concentration from cloned bacteria with pET-32a(+) plasmid after extraction by column of His-tag, also showing in this table first lysostaphin protein concentration 1.113 more than the third concentration of BSA 0.893 and less than second concentration of it 1.773. SDS-PAGE analysis of proteins showed in figure 5 with standard techniques, this figure showed only one protein band, this figure recoded lysostaphin molecular weight about 27,000 Dalton.

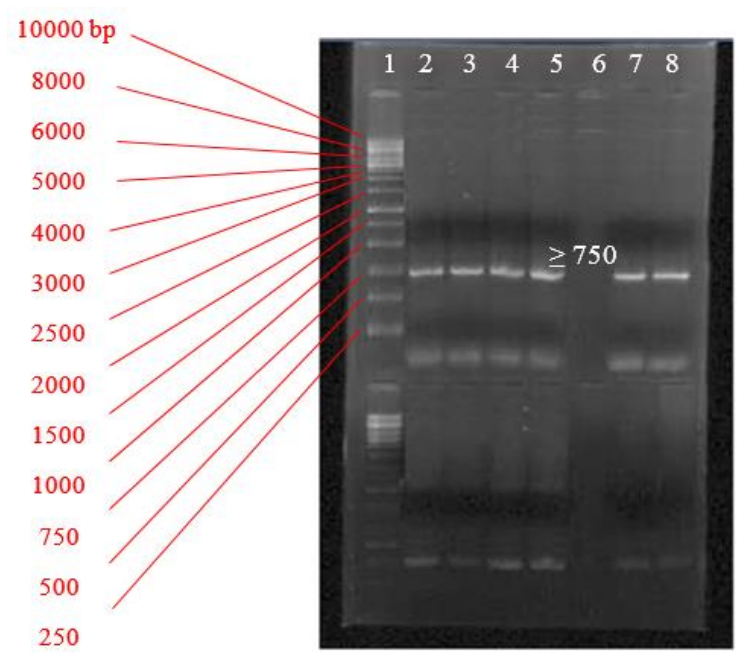

Figure 3: PCR product of lysostaphin gene from cloned bacteria by colony PCR, lane 1 is the ladder, lanes 2,3,4,5 are gene of lysostaphin from pET-32a(+) plasmid, lanes 7,8 are lysostaphin gene amplified by first detection about 750 $\mathrm{bp}$, lane 6 is negative control.

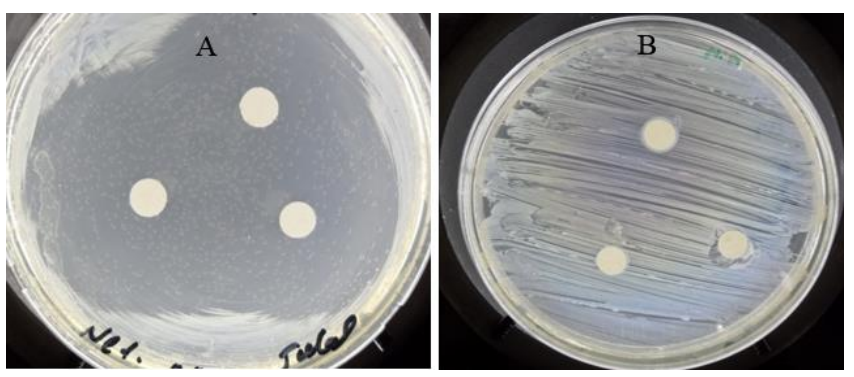

Figure 4: A. Effect of antibacterial activity of transformed E. coli by $\mathrm{pET}-32 \mathrm{a}(+)$ plasmid have lysostaphin gene against $S$. aureus, B. Effect of activity of antibacterial against $S$. aureus by non-transformed $E$. coli. 
Table 3: Lysostaphin protein concentration at the absorbance $595 \mathrm{~nm}$

\begin{tabular}{lcc}
\hline Bio-Rad dye & BSA & Lysostaphin from pET-32a(+) \\
\hline 0.329 & 2.989 & 1.113 \\
0.331 & 1.773 & 0.894 \\
0.323 & 0.893 & 0.689 \\
0.318 & 0.589 & 0.402 \\
0.332 & 0.371 & 0.345 \\
\hline
\end{tabular}

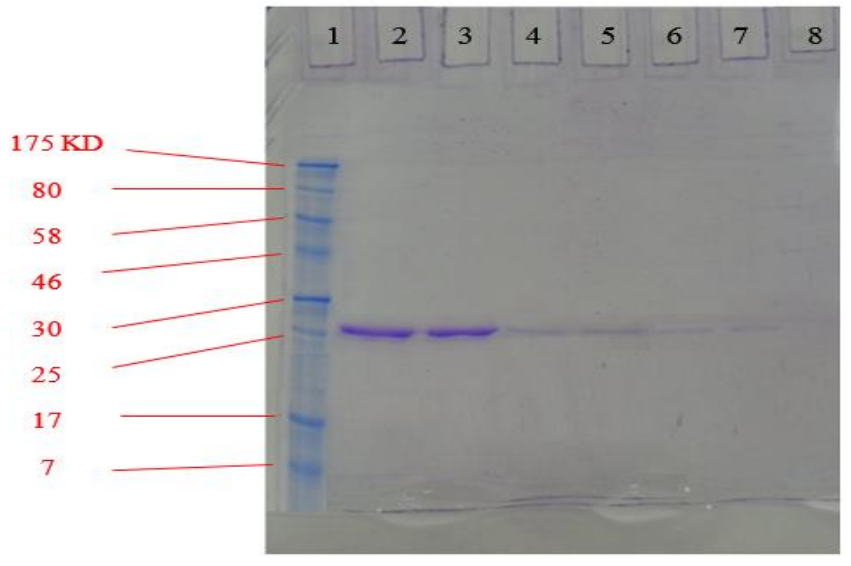

Figure 5: Lysostaphin protein in SDS-PAGE analysis, lane 1 is the marker, lanes 2,3 are lysostaphin protein extracted from cloning pET-32a(+) plasmid with first concentration, lines 4,5 second concentration, lines 6,7 the third concentration, and line 8 is negative control.

\section{Discussion}

Mastitis is one of the most important economic disease of dairy cattle, the effects of this disease come from resistance to treatment and costs losses (14). It is regarded as the first common disease, which causes losses of antibiotics by treatment in dairy cattle and responsible for antibiotics increasing resistance (15).

Mastitis treatment is very restricted and as a cause disease propagation, $S$. aureus is regarded a main cause of mastitis in the ruminants $(16,17)$. One of the studies for detection of capsulated $S$. aureus strains from bovine and buffaloes mastitis is Shamoon (18). S. aureus appears as a one of the twelve most health-threatening pathogens in the resistant bacterial list compiled by WHO which promotes new antibiotics development (19,20). Staphylococcal species and especially Staphylococcus aureus have developed resistance multidrug lead to serious risks of health then treatments complex, by using the novel and effective strategies development to kill these bacteria (21). To the present study gave a new strategy to treat this bacterial problem of $S$. aureus.

The result of the current study showed the size of gene of lysostaphin was $750 \mathrm{bp}$ which accepted by $(7,22,23)$.
The antibacterial activity of transformed $E$. coli have pET$32 \mathrm{a}(+)$, which showed the effect against $S$. aureus by $E$. coli non-transformed, this result agreement with the previously studies $(11,23)$, which recorded of effectiveness against $S$. aureus by transformed $E$. coli have lysostaphin active gene $750 \mathrm{bp}$.

SDS-PAGE analysis of proteins recoded the molecular weight of lysostaphin protein about 27,000 Dalton, this result matching by Mustafa; Trayer and Buckley $(11,24)$.

The result of the present study showed that limited increasing in concentration of lysostaphin protein when used pET-32a $(+)$ plasmid compared with other study (25), which recorded less then concentration of lysostaphin protein with other plasmid, this study recorded lysostaphin concentration from pTrc99a plasmid $1.012 \mathrm{mg} / \mathrm{ml}$ which less than our study $1.113 \mathrm{mg} / \mathrm{ml}$, as well as $0.622 \mathrm{mg} / \mathrm{ml}$ concentration by used pBAD30 plasmid.

In many study, the r-lysostaphin were produced from different pET vectors, pET28a is one of them which yield $22 \mathrm{mg}$, the other one is pET $23 \mathrm{~b}$ which yield $20 \mathrm{mg}$, and pET15b, yield $11 \mathrm{mg}$ of protein purified from one later of E. coli $(9,26,27)$. Our study gave successful of expressed lysostaphin gene by pET32a vector in E. coli, this protein production are mature r-lysostaphin because the activity against $S$. aureus and it is a large quantity of r-lysostaphin, this match and alignment with our data (9). It is found many different systems for expression have been developed, but the proteins recombinant production in $\mathrm{E}$. coli remains the most one used (28).

The activity of lysostaphin protein against $S$. aureus is because capability to lysis peptidoglycan of cell walls bacteria $(24,29)$. The site of action of lysostaphin protein is the cross-bridge pentaglycine of the peptidoglycan (30). Staphylococcal species in general and S. aureus is one of them composed of five glycine (Gly) residues (31). One of the antistaphylococcal agents is the lysostaphin, which is unique among in bacterial kills, it is have ability to killing a large number of organisms in the Staphylococcus genus because of the glycine-glycine bonds existence $(32,33)$. Lysostaphin enzyme consists of two domains, those are: Ncatalytic terminal domain and a cell wall binding domain (34).

Lysostaphin protein is a bacteriolytic metalloprotease secreted from $S$. simulans biovar staphylolyticus. It is function is degrading the staphylococci cell wall of multiple species by pentaglycine crosslinks hydrolysis within peptidoglycan (35).

\section{Conclusion}

We are conclude from succeeded pET-32a(+) plasmid to expressed lysostaphin gene and expressed protein lysostaphin in high quality and quantity. As well as conclude from our result, high accuracy of His tag technique in protein extraction and purification. 


\section{Aknowledgement}

We are Aknowledge the University of Basra, College of Veterinary Medicine, Public Health department for gave us all the facilities in the Public Health Lab.

\section{Conflict of interest}

Authors declares that they have no conflict of interest regarding publishing this review article.

\section{References}

1. Heng, NC, Wescombe PA, Burton JP, Jack RW, Tagg JR. In Riley MA, Chavan MA, editors. Bacteriocins: Ecology and evolution. New York: Springer; 2007. 45-92 p. Doi: 10.1007/s12602-008-9002-7

2. Cotter PD, Hill C, Ross RP. Bacteriocins: developing innate immunity for food. Nat Rev Mic. 2005;3:777-788. Doi: 10.1038/nrmicro1273

3. Bradley JS. Newer antistaphylococcal agents. Cur Opi Ped. 2005;17(1):71-77. doi: 10.1097/01.mop.0000151555.17799.41

4. Kokai-Kun JF, Walsh SM, Chanturiya T, Mond JJ. Lysostaphin cream eradicates Staphylococcus aureus nasal colonization in a cotton rat model. Ant Age Che. 2003;47:1589-1597. Doi: 10.1128/aac.47.5.1589-1597.2003

5. Sloan GL, Smith EC, Lancaster JH. Lysostaphin endopeptidasecatalysed transpeptidation reactions of the amino-transfer type. J Bio. 1977;167:293-296. Doi: 10.1128/aac.47.5.1589-1597.2003

6. Zygmunt WA, Harrison EF, Browder HP, Tavormina PA. Comparative inhibition of methicillin-resistant strains of Staphylococcus aureus by lysostaphin and other antibiotics. App Mic. 1968;16(8):1174-1178

https://www.ncbi.nlm.nih.gov/pmc/articles/PMC547615/pdf/applmicr o00244-0072.pdf

7. Recsei PA, Gruss AD, Novick RP. Cloning, sequence, and expression of the lysostaphin gene from Staphylococcus simulans. Pro Nat Aca Sci. 1987;84:1127-1131. Doi: 10.1073/pnas.84.5.1127

8. Heinrich P, Rosenstein R, Bohmer M, Sonner P, Gotz F. The molecular organization of the lysostaphin gene and its sequences repeated in tandem. Mol Gen Gen. 1987; 209:563-569. Doi: $10.1007 / \mathrm{bf00331163}$

9. Leila F, Ehsanollah GR, Neda M, Hamid A. Cloning, expression, and purification of recombinant lysostaphin from Staphylococcus simulans. Jundishapur J Mic. 2014;7(5):1-5. Doi: 10.5812/jjm.10009

10. Chant A, Kraemer-Pecore CM, Watkin R, Kneale GG. Attachment of a histidine tag to the minimal zinc finger protein of the Aspergillus nidulans gene regulatory protein AreA causes a conformational change at the DNA-binding site. Pro Exp Pur. 2005;39(2):152-159. Doi: 10.1016/j.pep.2004.10.017

11. Mustafa JY. Sequences and expression of the lysostaphin gene from Staphylococcus simulans isolated from bovine mastitis and its bactericidal effect on Staphylococcus aureus [PhD dissertation]. Bara: University of Basra, College of Science, Biology Department; 2011. $30-110 \mathrm{p}$

12. Sambrook J, Russell DW. Molecular cloning: A laboratory manual. New York: Cold Spring Harbor Laboratory Press; 2001. 59-78 p.

13. National Veterinary Institute (SVA). Department of Mastitis, Uppsala, Sweden. Accreditation Certificate, Methods File; 1998. 1-29 p.

14. Smith DL, Harris AD, Johnson JA, Silbergeld EK, Morris JJ. Animal antibiotic use has an early but important impact on the emergence of antibiotic resistance in human commensal bacteria. Pro Nat Aca Sci. 2002;99:6434-6439. Doi: 10.1073/pnas.082188899

15. Rajala-Schultz PJ, Smith KI, Hogan JS, Love BC. Antimicrobial susceptibility of mastitis pathogens from first lactation and older cows. J Vet Mic. 2004;102(1-2):33-42. Doi: 10.1016/j.vetmic.2004.04.010
16. Sol J. Summer mastitis: pathogenesis, losses, incidence and prevention. https://pubmed.ncbi.nlm.nih.gov/6349011/

17. Hussein SA. Isolation and identification of bacterial causes of clinical mastitis in cattle in Sulaimania region. Iraqi J of Vet Sci. 2008;22(1): 35-41. Doi: 10.33899/ijvs.2008.5666.

18. Shamoon GN. Detection of Staphylococcus aureus capsules producer isolated from bovine and buffaloes mastitis. Iraqi $\mathrm{J}$ of Vet Sci. 2008;20(1).39-47. Doi: 10.33899/ijvs.2006.45782

19. WHO Mediacentre. WHO publishes list of bacteria for which new antibiotics are urgently needed. 2017. https://www.who.int/newsroom/detail/27-02-2017-who-publishes-list-of-bacteria-for-whichnew-antibiotics-are-urgently-needed

20. Helena T, Vytas R, Linda K, Ulla P, Hannu M. Structural and functional insights into lysostaphin-substrate interaction. Fro Mol Bio. 2018;5(60):1-14. Doi: 10.3389/fmolb.2018.00060

21. Zeynep ED, Aişe Ü, Mehmet MÇ, Hayriye Ü, Barış B. Enhanced production of recombinant Staphylococcus simulans lysostaphin using medium engineering. J Pre Bio Bio. 2019;49(5): 521-528. Doi: 10.1080/10826068.2019.1599393

22. Bastos MC, Ceotto H, Coelho ML, Nascimento JS. Staphylococcal antimicrobial peptides: relevant properties and potential biotechnological applications. Cur Pha Bio. 2009;10(1):38-61. Doi: $10.2174 / 138920109787048580$

23. Chong A. Characterization of the virulence-related roles of the Legionella pneumophila chaperonin, $\mathrm{HtpB}$, in mammalian cells $[\mathrm{PhD}$ dissertation]. Nova Scotia: Dalhousie University Halifax; 2007. 79-81 p.

24. Trayer HR, Buckley III CE. Molecular properties of lysostaphin, a bacteriolytic agent specific for Staphylococcus aureus. J Bio Che. 1970;245(18):4842-4846. https://pubmed.ncbi.nlm.nih.gov/5456157/

25. Mustafa JY. Using two different promoters of lysostaphin gene to change protein production. Bas J Vet Res. 2014;1(2):141-150. https://www.iasj.net/iasj?func=article \&aId=98806

26. Zhang B, Shangguan T, Ma H, Huang X, Zhang Y. Lysis of mastitis pathogens isolated from dairy cow milk samples by purified recombinant lysostaphin. Afr J Bio. 2012;11:4649-5922. DOI: 10.5897/AJB11.2430

27. Szweda P, Kotlowski R, Kur J. New effective sources of the Staphylococcus simulans lysostaphin. J Bio. 2005;117(2):203-213. Doi: 10.1016/j.jbiotec.2005.01.012

28. Rosano, GL, Ceccarelli EA. Recombinant protein expression in Escherichia coli: Advances and challenges. Fro in Mic. 2014; 5, 1-17. Doi: 10.3389/fmicb.2014.00172

29. Browder HP, Zygmunt WA, Young JR, Tavormina PA. Lysostaphin: Enzymatic mode of action. Bioc Biop Res Com. 1965;19:383-389. Doi: 10.1016/0006-291x(65)90473-0

30. Grudling A, Schneewind O. Cross-linked peptidoglycan mediates lysostaphin binding to the cell wall envelope of Staphylococcus aureus. J. Bact. 2006;188:2463-2472. Doi: 10.1128/JB.188.7.24632472.2006

31. Schleifer KH, Fisher U. Description of a new species of the genus Staphylococcus: Staphylococcus carnosus. Int J Sys Bac. 1982;32:153-156. Doi: 10.1099/00207713-32-2-153

32. Chen C, Huahao F, Yong H, Fan P, Hang F. Recombinant lysostaphin protects mice from methicillin-resistant Staphylococcus aureus pneumonia. Bio Med Res Int. 2014:1-10. Doi: 10.1155/2014/602185

33. Hanson MR Chung CL. Antibiotic selection for MRSA: case presentations and review of the literature. J Drug Der. 2009;8(3):281286. https://pubmed.ncbi.nlm.nih.gov/19271378/

34. Paweł M, Elżbieta J, Elżbieta N, Janusz MB, Filip S, Dorota N, Matthias B, Izabela S. Structural bases of peptidoglycan recognition by lysostaphin SH3b domain. Sci Rep. 2019;9:5965. Doi: 10.1038/s41598-019-42435-z

35. Anna M, Agnieszka J, Grzegorz D, Benedykt W. Production of lysostaphin by nonproprietary method utilizing a promoter from toxinantitoxin system. Mol Bio. 2019;61:774-782. Doi: 10.1007/s12033019-00203-4 
جين اللايسوستافين من المكورات العنقودية نوع سميلنس، وكان حجم

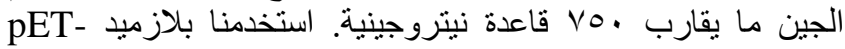

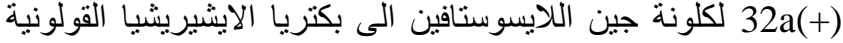

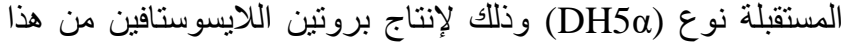

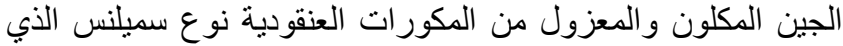

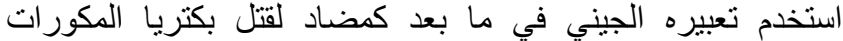

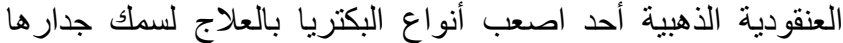

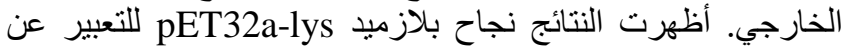

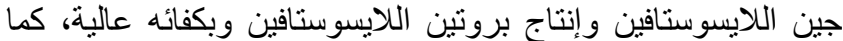

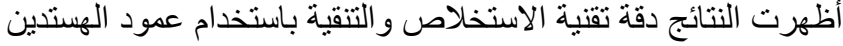

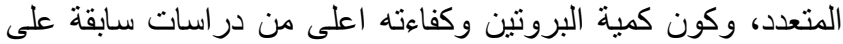

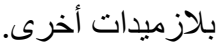

دراسة تأثير كلونة بلازميا مET-32a(+) بلافين اللايسوستافين ضد بكتريا المكورات العنقودية الذهبية

\section{جلال ياسين مصطقى}

فرع الصحة العامة البيطرية، كلية الطب البيطري، جامعة البصرة، البصرة، العر اق اق العان

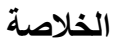

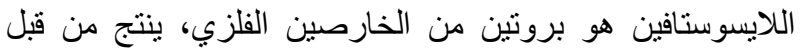
بكتيريا المكورات العنقودية نوع سميلنس، يعمل على لئ تحطيم الجدار البيتيدي لبكتريا المكورات العنقودية الذهبية. في هذه الدراسة تم عزل نعل الديل 